\title{
Front Matter: Volume 6438
}

, "Front Matter: Volume 6438," Proc. SPIE 6438, Biophotonics and Immune Responses II, 643801 (12 March 2007); doi: 10.1117/12.727311

SPIE. Event: SPIE BiOS, 2007, San Jose, California, United States 


\section{PROGRESS IN BIOMEDICAL OPTICS AND IMAGING}

Vol. 8, No. 15

\section{Biophotonics and Immune Responses II}

Wei R. Chen

Editor

22-23 January 2007

San Jose, California, USA

Sponsored and Published by

SPIE-The International Society for Optical Engineering

Volume 6438

The International Society for Optical Engineering

Proceedings of SPIE-The International Society for Optical Engineering, 9780819465511, v. 6438

SPIE is an international technical society dedicated to advancing engineering and scientific applications of optical, photonic, imaging, electronic, and optoelectronic technologies. 
The papers included in this volume were part of the technical conference cited on the cover and title page. Papers were selected and subject to review by the editors and conference program committee. Some conference presentations may not be available for publication. The papers published in these proceedings reflect the work and thoughts of the authors and are published herein as submitted. The publisher is not responsible for the validity of the information or for any outcomes resulting from reliance thereon.

Please use the following format to cite material from this book:

Author(s), "Title of Paper," in Biophotonics and Immune Responses II, edited by Wei R. Chen, Proceedings of SPIE Vol. 6438 (SPIE, Bellingham, WA, 2007) Article CID Number.

ISSN $1605-7422$

ISBN 9780819465511

Published by

SPIE-The International Society for Optical Engineering

P.O. Box 10, Bellingham, Washington 98227-0010 USA

Telephone 1 360/676-3290 (Pacific Time) · Fax 1 360/647-1445

http://www.spie.org

Copyright @ 2007 , The Society of Photo-Optical Instrumentation Engineers

Copying of material in this book for internal or personal use, or for the internal or personal use of specific clients, beyond the fair use provisions granted by the U.S. Copyright Law is authorized by SPIE subject to payment of copying fees. The Transactional Reporting Service base fee for this volume is $\$ 18.00$ per article (or portion thereof), which should be paid directly to the Copyright Clearance Center (CCC), 222 Rosewood Drive, Danvers, MA 01923. Payment may also be made electronically through CCC Online at http://www.copyright.com. Other copying for republication, resale, advertising or promotion, or any form of systematic or multiple reproduction of any material in this book is prohibited except with permission in writing from the publisher. The CCC fee code is $1605-$ $7422 / 07 / \$ 18.00$.

Printed in the United States of America. 


\section{Contents}

vii Conference Committee

\section{SESSION 1 PDT AND IMMUNE ACTIVITIES}

643802 Advances in the understanding of host response associated with fumor PDT (Invited Paper) [6438-01]

M. Korbelik, British Columbia Cancer Agency (Canada)

643803 Photodynamic therapy stimulates anti-tumor immunity in a murine model (Invited Paper) [6438-02]

P. Mroz, A. P. Castano, Wellman Ctr. for Photomedicine, Massachusetts General Hospital (USA), and Harvard Medical School (USA); M. X. WU, Wellman Ctr. for Photomedicine, Massachusetts General Hospital (USA), Harvard Medical School (USA), and Harvard-MIT Division of Health Sciences and Technology (USA); A. L. Kung, Dana-Farber Cancer Institute (USA); M. R. Hamblin, Wellman Ctr. for Photomedicine, Massachusetts General Hospital (USA), Harvard Medical School (USA), and Harvard-MIT Division of Health Sciences and Technology (USA)

\section{SESSION 2 CLINICAL STUDIES I}

643807 In situ photoimmunotherapy for melanoma: an ongoing phase I clinical trial [6438-06] M. F. Naylor, Univ. of Oklahoma College of Medicine (USA); R. E. Nordquist, Advanced Cancer Therapies LLC (USA); T. K. Teague, Univ. of Oklahoma College of Medicine (USA), Univ. of Oklahoma College of Pharmacy (USA), and Oklahoma State Univ. Ctr. for Health Sciences (USA); L. A. Perry, Univ. of Oklahoma College of Medicine (USA); W. R. Chen, Univ. of Central Oklahoma (USA)

\footnotetext{
Pagination: Proceedings of SPIE follow an e-First publication model, with papers published first online and then in print and on CD-ROM. Papers are published as they are submitted and meet publication criteria. A unique, consistent, permanent citation identifier (CID) number is assigned to each article at the time of the first publication. Utilization of CIDs allows articles to be fully citable as soon they are published online, and connects the same identifier to all online, print, and electronic versions of the publication.

SPIE uses a six-digit CID article numbering system in which:

- The first four digits correspond to the SPIE volume number.

- The last two digits indicate publication order within the volume using a Base 36 numbering system employing both numerals and letters. These two-number sets start with 00, 01, 02, 03, 04, 05, 06, 07, 08, 09, 0A, 0B ... 0Z, followed by 10-1Z, 20-2Z, etc.

The CID number appears on each page of the manuscript. The complete citation is used on the first page, and an abbreviated version on subsequent pages.
} 
643809 Imiquimod immunotherapy and ALA photodynamic therapy combination for the treatment of genital bowenoid papulosis (Invited Paper) [6438-08]

X.-L. Wang, H.-W. Wang, M.-X. Guo, Shanghai Skin Diseases and STD Hospital (China);

Z. Huang, Univ. of Colorado at Denver and Health Sciences Ctr. (USA)

64380A Clinical pharmacokinetics of protoporphyrin IX (PpIX) in condylomata acuminata patients: ex vivo fluorescence examination [6438-09]

X.-L. Wang, H.-W. Wang, Shanghai Skin Diseases and STD Hospital (China); Z. Huang, Univ. of Colorado at Denver and Health Sciences Ctr. (USA); H. Stepp, R. Baumgartner, C. Dannecker, Munich Univ. (Germany); P. Hillemanns, Medical School of Hannover (Germany)

SESSION 4 PHOTOTHERMAL INTERACTIONS AND IMMUNE ACTIVITIES

64380B Cellular immunological effects of laser irradiation and immunoadjuvant application (Invited Paper) [6438-10]

W. R. Chen, A. Mohamed, Univ. of Central Oklahoma (USA); M. F. Naylor, Univ. of Oklahoma College of Medicine (USA); K. E. Bartels, J. W. Ritchey, Oklahoma State Univ. (USA); H. Liu, Univ. of Oklahoma (USA); R. E. Nordquist, Advanced Cancer Therapies LLC (USA)

64380C Tissue temperature distribution measurement by MRI and laser immunology for cancer treatment [6438-11]

Y. Chen, Univ. of Central Oklahoma (USA); S. C. Gnyawali, Oklahoma State Univ. (USA); F. WU, Chongqing Medical Univ. (China); H. Liu, Univ. of Oklahoma (USA); Y. A. Tesiram, A. Abbott, R. A. Towner, Oklahoma Medical Research Foundation (USA); W. R. Chen, Univ. of Central Oklahoma (USA)

64380D Determination of surface temperature distribution in biological tissues during laserimmunotherapy [6438-12]

S. C. Gnyawali, Oklahoma State Univ. (USA); Y. Chen, Univ. of Central Oklahoma (USA);

F. Wu, Chongqing Univ. of Medical Sciences (China); K. E. Bartels, J. W. Ritchey,

J. P. Wicksted, Oklahoma State Univ. (USA); H. Liu, Univ. of Oklahoma (USA); W. R. Chen, Univ. of Central Oklahoma (USA)

\section{SESSION 5 LASER INDUCED CELLULAR ACTIVITIES}

64380E Single cell analysis of low-power laser irradiation-induced activation of signaling pathway in cell proliferation (Invited Paper) [6438-13]

D. Xing, X. Gao, South China Normal Univ. (China)

$64380 \mathrm{G}$ Real-time single cell analysis of bid cleavage and translocation in cisplatin-induced apoptosis [6438-15]

L. Liu, D. Xing, Y. Pei, South China Normal Univ. (China); W. R. Chen, South China Normal

Univ. (China) and Univ. of Central Oklahoma (USA) 
64380I Sonodynamic cytotoxic effect of hematoporphyrin monomethyl ether on C6 glioma cells: in vitro study [6438-17]

W. Yue, D. Song, Z. Zhao, S. Cao, X. Meng, X. Zhang, Harbin Medical Univ. (China);

Z. Huang, Colorado Univ. of Health Sciences Ctr. (USA)

\section{POSTER SESSION}

64380J Fluorescence spectroscopy to assess apoptosis in myocardium [6438-18]

M. Ranji, M. Matsubara, M. A. Grosso, D. L. Jaggard, B. Chance, R. C. Gorman,

J. H. Gorman III, Univ. of Pennsylvania (USA)

64380K Optical imaging the redox status change during cell apoptosis [6438-19]

T. Su, Z. Zhang, J. Lin, Q. Luo, Huazhong Univ. of Science and Technology (China)

$64380 \mathrm{~L}$ Monitoring the concentration and oxygen saturation of hemoglobin using photoacoustic technique [6438-20]

Y.-X. SU, Tianjin Univ. (China); R. K. Wang, Tianjin Univ. (China) and Oregon Health and Science Univ. (USA); T. LU, Z.-Y. Song, Tianjin Univ. (China)

$64380 \mathrm{M}$ Photodynamic therapy induced production of cytokines by latent Epstein Barr virus infected epithelial tumor cells [6438-21]

H. K. Koon, Hong Kong Baptist Univ. (Hong Kong China); K. W. Lo, Prince of Wales Hospital, The Chinese Univ. of Hong Kong (Hong Kong China); M. L. Lung, C. K. C. Chang, Hong Kong Univ. of Science and Technology (Hong Kong China); R. N. S. Wong, N. K. Mak, Hong Kong Baptist Univ. (Hong Kong China)

$64380 \mathrm{~N}$ Lasting monitoring of immune state in patients with coronary atherosclerosis [6438-22] L. I. Malinova, Saratov Scientific Research Institute of Cardiology (Russia) and Saratov State Medical Univ. (Russia); T. P. Denisova, Saratov State Medical Univ. (Russia); V. V. Tuchin, Saratov State Univ. (Russia)

Author Index 
Downloaded From: https://www.spiedigitallibrary.org/conference-proceedings-of-spie on 26 Apr 2023

Terms of Use: https://www.spiedigitallibrary.org/terms-of-use 


\title{
Conference Committee
}

\author{
Symposium Chairs
}

James G. Fujimoto, Massachusetts Institute of Technology (USA)

R. Rox Anderson, Wellman Center for Photomedicine (USA), Massachusetts General Hospital (USA), and Harvard School of Medicine (USA)

Program Track Chairs

Steven L. Jacques, Oregon Helath and Science University (USA)

William P. Roach, Air Force Research Laboratory (USA)

Conference Chair

Wei R. Chen, University of Central Oklahoma (USA)

Program Committee

Samuel Achilefu, Washington University in St. Louis (USA)

Gianfranco L. Canti, Università degli Studi di Milano (Italy)

Yuncheng Ge, Beijing Glass Research Institute (China)

Sandra O. Gollnick, Roswell Park Cancer Institute (USA)

Michael R. Hamblin, Harvard Medical School (USA)

Zheng Huang, University of Colorado at Denver (USA)

Mladen Korbelik, British Columbia Cancer Agency (Canada)

Karl-Goran Tranberg, Lunds Universitet (Sweden)

Xunbin Wei, Harvard Medical School (USA)

Vladimir P. Zharov, University of Arkansas for Medical Sciences (USA)

\section{Session Chairs}

1 PDT and Immune Activities

Mladen Korbelik, British Columbia Cancer Agency (Canada)

Sandra O. Gollnick, Roswell Park Cancer Institute (USA)

2 Clinical Studies I

Feng Wu, Churchill Hospital (United Kingdom) and Chongqing University of Medical Sciences (China)

Mark F. Naylor, Oklahoma Medical Research Foundation (USA) and University of Oklahoma College of Medicine

3 Clinical Studies II

Zheng Huang, University of Colorado at Denver (USA) 
$4 \quad$ Photothermal Interactions and Immune Activities

Wei R. Chen, University of Central Oklahoma (USA)

$5 \quad$ Laser-Induced Cellular Activities

Wei R. Chen, University of Central Oklahoma (USA) 